\title{
Seasonal and diurnal variations of atmospheric peroxyacetyl nitrate, peroxypropionyl nitrate, and carbon tetrachloride in Beijing
}

\author{
Gen Zhang, Yujing Mu*, Junfeng Liu, Chenglong Zhang, Yuanyuan Zhang, Yujie Zhang, Hongxing Zhang
}

Research Center for Eco-Environmental Sciences, Chinese Academy of Sciences, Beijing 100085, China. E-mail: zg348195277@163.com

\section{A R T I C L E I N F O}

\section{Article history:}

Special issue: Progress and prospects of atmospheric environmental science in China

\section{Keywords:}

atmospheric peroxyacetyl nitrate peroxypropionyl nitrate

carbon tetrachloride

Beijing

atmosphere

DOI: 10.1016/S1001-0742(13)60382-4

\begin{abstract}
A B S T R A C T
Atmospheric peroxyacetyl nitrate (PAN), peroxypropionyl nitrate (PPN), and carbon tetrachloride $\left(\mathrm{CCl}_{4}\right)$ were measured from September 2010 to August 2011 in Beijing. PAN exhibited low values from mid-autumn to early spring (October to March) with monthly average concentrations ranging from 0.28 to $0.73 \mathrm{ppbV}$, and increased from early spring to summer (March to August), ranging from 1.37-3.79 ppbV. The monthly variation of PPN was similar to PAN, with low values (below detection limit to $0.18 \mathrm{ppbV}$ ) from mid-autumn to early spring, and a monthly maximum in September (1.14 $\mathrm{ppbV})$. The monthly variation of $\mathrm{CCl}_{4}$ was tightly related to the variation of temperature, exhibiting a minimum in winter (69.3 pptV) and a maximum of $180.6 \mathrm{pptV}$ in summer. Due to weak solar intensity and short duration, PAN and $\mathrm{O}_{3}$ showed no distinct diurnal patterns from morning to night during winter, whereas for other seasons, they both exhibited maximal values in the late afternoon (ca. 15:00 to 16:00 local time) and minimal values during early morning and midnight. Good linear correlations between PAN and PPN were found in autumn $(R=0.91)$, spring $(R=0.94)$, and summer $(R=0.81)$, with slopes of $0.130,0.222$, and 0.133 , respectively, suggesting that anthropogenic hydrocarbons dominated the photochemical formation of PANs in Beijing. Positive correlation between $\mathrm{PAN}$ and $\mathrm{O}_{3}$ in summer with the low slopes $\left(\Delta \mathrm{O}_{3} / \triangle \mathrm{PAN}\right)$ ranging from 9.92 to 18.0 indicated serious air pollution in Beijing, and strong negative correlation in winter reflected strong $\mathrm{O}_{3}$ consumption by $\mathrm{NO}$ titration and less thermal decompositin of PAN.
\end{abstract}

\section{Introduction}

Peroxyacetyl nitrate (PAN), peroxypropionyl nitrate (PPN), and other homologue compounds (thereafter related to PANs, $\left.\mathrm{RC}(\mathrm{O}) \mathrm{OONO}_{2}\right)$ are crucial components of the odd-nitrogen compounds (NOy) in the atmosphere and particularly important secondary pollutants formed via photochemical reactions of volatile organic compounds (VOCs) in the presence of NOx (Aikin et al., 1982; Singh, 1987; Singh and Hanst, 1981). PANs play important roles in atmospheric chemistry and have adverse impacts on human health and ecosystems. PAN, as the most abundant species among PANs, has been recognized as lachrymators

\footnotetext{
${ }^{*}$ Corresponding author. E-mail: yjmu@ $@$ rcees.ac.cn
}

(Altshuller, 1978), mutagens (Shepson et al., 1986), and phytotoxins (Sun and Huang, 1995; Taylor, 1969). PPN as the second largest species among PANs, its atmospheric concentration usually accounts for $4 \%-20 \%$ of PAN (Grosjean et al., 2001, 2002; Lee et al., 2008; Zhang et al., 2011), and it is four times phytotoxic (Kleindienst et al., 1990) and five times eye-irritant than that of PAN (Altshuller, 1978). Furthermore, PAN and some of its analogues have been found to 10-50 times toxic to the plant than that of $\mathrm{O}_{3}$ (Gaffney and Marley, 2001a, 2001b; Taylor, 1969). Atmospheric PAN is exclusively from tropospheric photochemical reactions, and hence, PAN has been considered as a better indicator of photochemical smog pollution than $\mathrm{O}_{3}$ (McFadyen and Cape, 2005). PANs are thermal unstable compounds, they are quite stable in the midand upper troposphere under low temperature, and can be 
transported over long distances from polluted continental regions into the remote areas where they release $\mathrm{NO} x$ under high temperature (Honrath et al., 1996; Kondo et al., 1997; Singh et al., 1996), and hence PANs act as important temporary NO $x$ reservoirs and control the photochemical production of $\mathrm{O}_{3}$ in the remote troposphere (Singh and Hanst, 1981). Due to the particular importance of PANs on atmospheric chemistry, a great number of PANs measurements have been conducted intensively in developed countries, including the urban regions (Grosjean et al., 2001; Marley et al., 2007; Roberts et al., 1995) and remote area (Hartsell et al., 1994; Roberts et al., 2004; Singh et al., 1990, 1992; Williams and Grosjean, 1991). However, only few researches involving with PANs are implemented in developing countries of Asia (Lee et al., 2008; Watanabe et al., 1998; Zhang and Tang, 1994; Wang et al., 2010; Zhang et al., 2009).

Carbon tetrachloride $\left(\mathrm{CCl}_{4}\right)$, another species investigated in this work, is widely used in the synthesis of chlorofluorocarbons and as a solvent in the past chemical processes (Altshuller, 1976). $\mathrm{CCl}_{4}$ is chemical inert in the troposphere, difficult to photolysis and non-reactive towards the tropospheric oxidants (Cox et al., 1976). Therefore, the emitted $\mathrm{CCl}_{4}$ can ultimately diffuse into the stratosphere where it will release chlorine atoms under the intensive ultraviolet sunlight irradiation and participate in stratospheric ozone depletion (Molina and Rowland, 1974). To date, numerous global observation networks have been established for $\mathrm{CCl}_{4}$ in the developed countries (Derwent et al., 1998; Happell and Roche, 2003; Lovelock et al., 1973; Simmonds et al., 1988), but very limited measurements in China (Barletta et al., 2006; Sun et al., 2010; Yao et al., 2010).

Beijing, the capital of China, is suffering from serious photo-oxidants pollution as indicated by elevation of $\mathrm{O}_{3}$ (Gao and Zhang, 2012; Shao et al., 2009; Tang et al., 2009; Wang et al., 2006; Zhang et al., 2004). However, the measurements of PANs as the indicator of photochemical pollution, in the megacity are relatively sparse (Wang and Zhang, 2007; Yang et al., 2009; Zhang et al., 2011), and the existing studies mostly carried out over short period during summer, generally a few weeks.

In this study, we conducted measurements of atmospheric PAN, PPN, $\mathrm{CCl}_{4}$, and $\mathrm{O}_{3}$ from September 2010 to August 2011 in Beijing, and elucidated the seasonal and diurnal variations of $\mathrm{PAN}, \mathrm{O}_{3}$, and $\mathrm{CCl}_{4}$.

\section{Experimental}

\subsection{Site description}

Field measurements were conducted on the sixth floor of the Environmental Technological Building $(20 \mathrm{~m}$ above the ground level) in the Research Center for EcoEnvironmental Sciences (RCEES), which is located in the north of Beijing $\left(40.0^{\circ} \mathrm{N}, 116.3^{\circ} \mathrm{E}\right)$. The surroundings of RCEES are several institutes, campuses, residential apartments, and two side roads with moderate traffic. The RCEES is moderately covered by various plants, including P. orientalis, Pendula loud, P. simonii, and S. matsudana koidz.

\subsection{Determination of $\mathrm{PANs}$ and $\mathrm{CCl}_{4}$}

Atmospheric PANs and $\mathrm{CCl}_{4}$ were measured by HP5890 gas chromatography equipped with ${ }^{63} \mathrm{Ni}$ electron capture detector and a capillary column DB-1 (30 m length, $0.32 \mathrm{~mm}$ ID, Agilent Company). The information about operation condition and calibration of the instrument was essentially identical to our previous study (Zhang et al., 2012). Briefly, the GC oven and detector temperatures were maintained at $20^{\circ} \mathrm{C}$ and $38^{\circ} \mathrm{C}$ respectively. The carrier gas helium $(99.999 \%)$ and make-up gas $\mathrm{N}_{2}$ (99.999\%) flow rates were adjusted to be 8 and $54 \mathrm{~mL} / \mathrm{min}$, respectively. Air sample was drawn into the GC loop $(0.5$ $\mathrm{mL}$ ) by a minipump (NMP830KNDC, KNF Inc.) via a Teflon tube ( $3 \mathrm{~mm}$ OD, $6 \mathrm{~m}$ length) with a flow rate of $1.5 \mathrm{~L} / \mathrm{min}$. Each sampling time was $20 \mathrm{sec}$ and the pressure was equilibrated for $5 \mathrm{sec}$ with the pump power off, and then six-port valve (MGS-4, Shimadzu, Japan) was switched for GC-ECD analysis. The analyzing frequency was set to $30 \mathrm{~min}$. The instrument calibrations for PAN and PPN were carried out by evaporation of synthesized PAN and PPN solution in a Teflon bag, and the concentrations of PAN and PPN in the solutions were quantified by IC based on the quantitative conversion of PAN and PPN to $\mathrm{NO}_{2}{ }^{-}$under hydrolysis in sodium hydroxide solution. For calibration of $\mathrm{CCl}_{4}$, gaseous $\mathrm{CCl}_{4}$ was also obtained via the volatilization of a known amount of liquid $\mathrm{CCl}_{4}$ into $10 \mathrm{~L}$ Teflon bag at $50^{\circ} \mathrm{C}$ and followed by $\mathrm{GC}$ analysis. The overall uncertainties for measuring atmospheric PAN and PPN were estimated to be $\pm 13 \%$, and for $\mathrm{CCl}_{4}$ was approximately $\pm 5 \%$. The detection limits (three times the signal to noise ratio, $3 \mathrm{~S} / \mathrm{N}$ ) for PAN, $\mathrm{PPN}$ and $\mathrm{CCl}_{4}$ were estimated to be 22,36 , and $5 \mathrm{pptV}$, respectively.

\subsection{Determination of ambient $\mathrm{O}_{3}$ and NOx}

The measurements of ambient ozone and NOx were simultaneously conducted from September 2010 to August 2011 using Model 49i ozone analyzer and Model 42i NO $x$ analyzer (Thermo Scientific, USA), respectively. The $\mathrm{O}_{3}$ analyzer was calibrated by using Thermo Scientific Model 49i-PS ozone calibrator once every 3 months. The detection limit $(3 \mathrm{~S} / \mathrm{N})$ for ozone measurement was $1 \mathrm{ppbV}$, and the total measurement uncertainty was about $5 \%$. For the calibration of NOx analyzer, it was achieved by Thermo Scientific Model 146i with NO standard gas. The detection limit $(3 \mathrm{~S} / \mathrm{N})$ for $\mathrm{NO} x$ measurement was $0.4 \mathrm{ppbV}$, and the total measurement uncertainty was estimated to be $5 \%$. 

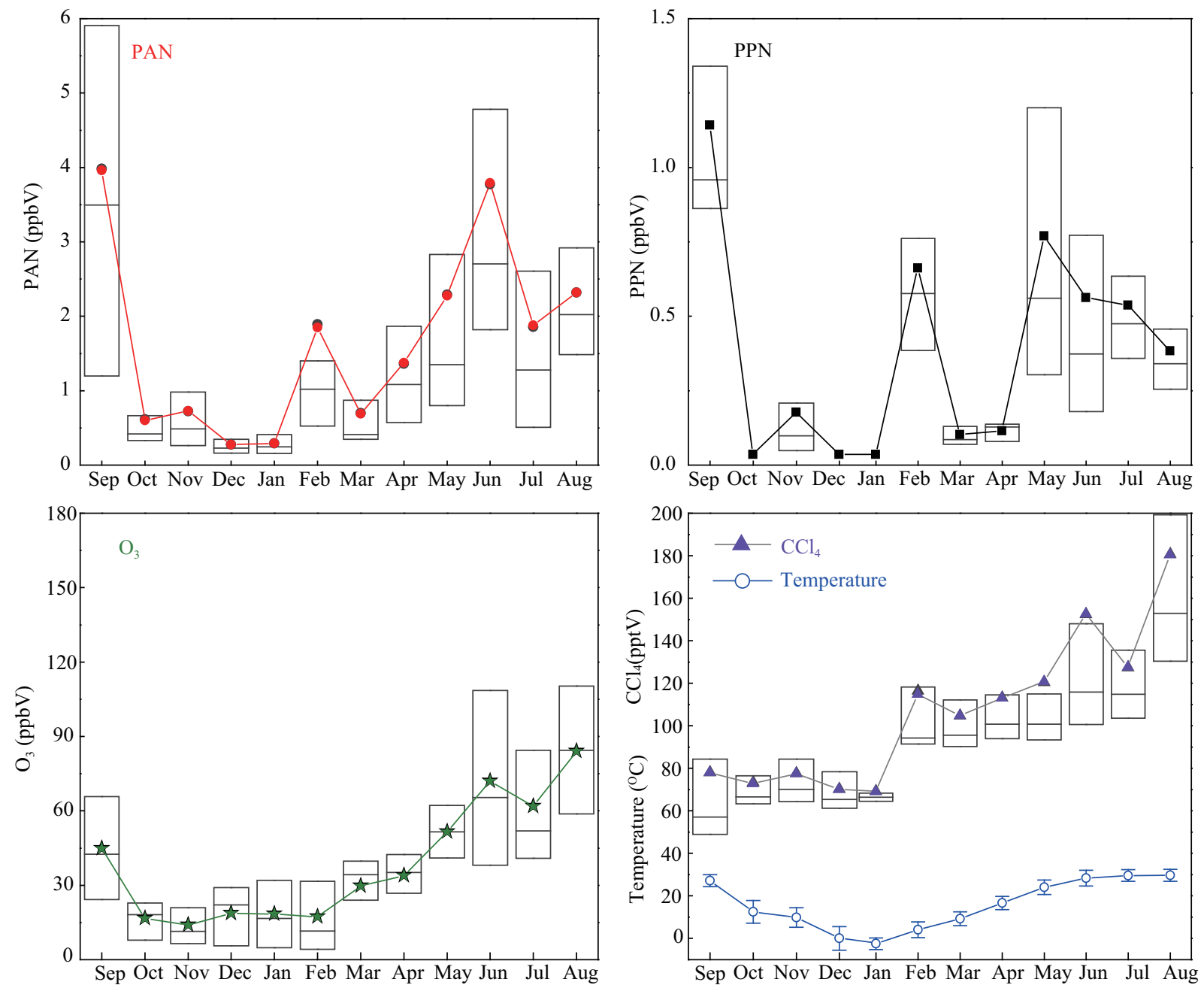

Fig. 1 Monthly variations of PAN, PPN, $\mathrm{O}_{3}, \mathrm{CCl}_{4}$ and Temperature. Monthly averages (with error bar ( $\left.\pm 1 \sigma\right)$ for temperature), medians (dashes in the rectangles), 25th percent (bottom of rectangles), and 75th (top of rectangles).

\section{Results and discussion}

\subsection{Monthly variations}

The monthly variations of PAN, $\mathrm{PPN}, \mathrm{O}_{3}$, and $\mathrm{CCl}_{4}$ are illustrated in Fig. 1. It should be mentioned that the concentrations of PPN in October, December, and January were below the detection limit of instrument $(3 \mathrm{~S} / \mathrm{N}=$ $36 \mathrm{pptV}$ ), and $0.036 \mathrm{ppbV}$ was used as the monthly mean PPN concentrations for these months. As shown in Fig. 1, both common and different characters among the monthly variations of the four pollutants could be seen. Because atmospheric PAN, PPN and $\mathrm{O}_{3}$ are the secondary pollutants from photochemical reactions of VOCs and $\mathrm{NO} x$, the sharply decrease of PAN, PPN and $\mathrm{O}_{3}$ from September to October was ascribed to the decrease of sunlight intensity and duration (Fig. 1d). Pulse increase of PAN and PPN were observed in February, but $\mathrm{O}_{3}$ in this month kept as constant low value as other months in winter. It should be mentioned that stagnant air condition with bad atmospheric visibility (usually called haze day) frequently occurred in February 2011, and serious accumulation of primary pollutants was observed, e.g., the daily mean concentration of $\mathrm{NO}$ on 23 February achieved $70.7 \mathrm{ppbV}$ and of $\mathrm{NO}_{2}$ was $84.5 \mathrm{ppbV}$. The weak sunlight under the haze days might not efficiently trigger $\mathrm{NO}_{2}$ photolysis to form $\mathrm{O}_{3}$ (Reactions (4)-(5)), and the titration of the high concentration of $\mathrm{NO}$ on $\mathrm{O}_{3}$ (Reaction (6)) greatly suppressed $\mathrm{O}_{3}$ concentration as well. As for PAN and PPN, their thermal decomposition rates become extremely low under the extremely low air temperature in the winter (Reactions (8)-(11)), and hence the formed PAN and PPN through the reactions of $\mathrm{OH}$ with VOCs could be easily accumulated under the stagnant air condition (Reactions (1), (2), and (7)).

$$
\begin{aligned}
& \mathrm{RH}+\mathrm{OH} \longrightarrow \mathrm{R}+\mathrm{H}_{2} \mathrm{O} \\
& \mathrm{R}+\mathrm{O}_{2} \longrightarrow \mathrm{RO}_{2} \\
& \mathrm{RO}_{2}+\mathrm{NO} \longrightarrow \mathrm{RO}+\mathrm{NO}_{2} \quad \mathrm{NO}_{2}+h v \rightarrow \mathrm{NO}+\mathrm{O} \\
& \mathrm{O}+\mathrm{O}_{2}+\mathrm{M} \longrightarrow \mathrm{O}_{3}+\mathrm{M}
\end{aligned}
$$




$$
\begin{aligned}
& \mathrm{O}_{3}+\mathrm{NO} \longrightarrow \mathrm{NO}_{2}+\mathrm{O}_{2} \\
& \mathrm{RO}_{2}\left(\mathrm{CH}_{3} \mathrm{COOO}_{2}, \mathrm{CH}_{3} \mathrm{CH}_{2} \mathrm{COOO}_{2}\right) \stackrel{\mathrm{NO}_{2}}{\longrightarrow} \\
& \mathrm{CH}_{3} \mathrm{COOO}_{2} \mathrm{NO}_{2}(\mathrm{PAN}), \mathrm{CH}_{3} \mathrm{CH}_{2} \mathrm{COOO}_{2} \mathrm{NO}_{2}(\mathrm{PPN})
\end{aligned}
$$

$$
\begin{aligned}
& \mathrm{PAN} \longrightarrow \mathrm{CH}_{3} \mathrm{COOO}_{2}+\mathrm{NO}_{2} \\
& \mathrm{PPN} \longrightarrow \mathrm{CH}_{3} \mathrm{CH}_{2} \mathrm{COOO}_{2}+\mathrm{NO}_{2} \\
& \mathrm{CH}_{3} \mathrm{COOO}_{2}+\mathrm{NO} \longrightarrow \mathrm{CH}_{3} \mathrm{CO}+\mathrm{NO}_{2}+\mathrm{O}_{2} \\
& \mathrm{CH}_{3} \mathrm{CH}_{2} \mathrm{COOO}_{2}+\mathrm{NO} \longrightarrow \mathrm{CH}_{3} \mathrm{CH}_{2} \mathrm{CO}+\mathrm{NO}_{2}+\mathrm{O}_{2}
\end{aligned}
$$

The abnormal high concentrations of PAN and PPN in February, especially on the haze days (e.g., on 23 February their daily mean concentrations were as high as $5.71 \mathrm{ppbV}$ and $0.68 \mathrm{ppbV}$, respectively), also indicated that high $\mathrm{OH}$ radicals existed in the atmosphere because of PAN and PPN exclusively from secondary formation. Due to the weak sunlight and low concentration of $\mathrm{O}_{3}$ on haze days, the sources of $\mathrm{OH}$ from photolysis of $\mathrm{O}_{3}$ and $\mathrm{HCHO}$ as well as the reactions of $\mathrm{O}_{3}$ with unsaturated alkenes should be negligible. Because photolysis of HONO can easily form $\mathrm{OH}$ radical under weak sunlight irradiation, HONO formed from the heterogeneous reaction of $\mathrm{NO}_{2}$ on air particle surface was suspected to be responsible for the high $\mathrm{OH}$ concentration in haze days. The maximal monthly average concentrations of PAN and PPN were observed in September, while $\mathrm{O}_{3}$ occurred in August. Although formation potentials for PAN and PPN in August should be greater than in September due to stronger sunlight irradiation, the thermal decomposition of them under higher temperature in August would greatly counteract their formation potentials. In contrast, $\mathrm{O}_{3}$ is a thermal stable compound, and the atmospheric concentrations of $\mathrm{O}_{3}$ mainly depend upon photochemical reactivity which has been found to be greatest in August in Beijing (Gao and Zhang, 2012). Although PAN and PPN have very similar formation mechanisms, the monthly variations of them were not identical due to their different VOCs precursors, e.g., the second maximal average values for PAN and PPN appeared in July and in May, respectively. As for $\mathrm{CCl}_{4}$, the monthly variation was similar to air temperature, indicating atmospheric $\mathrm{CCl}_{4}$ in Beijing was mainly from evaporation of solvents. Because air temperature reflects both sunlight intensity and evaporation rates for solvents, the monthly variation of $\mathrm{CCl}_{4}$, only with the exception in February, was almost concurrent with that of $\mathrm{O}_{3}$. As mentioned above, frequent haze days occurred in the February, which favored for pollutants accumulation, e.g., the daily mean concentration of $\mathrm{CCl}_{4}$ achieved to extremely high value of $190.4 \mathrm{pptV}$ on 23 February.

To compare with previous studies in Beijing, more detail information about the sample number, the mean, median and maximal values in each month are summarized in Table 1. The maximal concentrations (12.52 ppbV for
PAN in September 2010, and $2.50 \mathrm{ppbV}$ for PPN in May 2011) observed in this study were in the range of the reported maximal values of 2.49-17.8 ppbV for PAN and 0.5-2.48 ppbV for PPN in Beijing (Wang and Zhang, 2007; Xu et al., 2011; Yang et al., 2009). The mean $\mathrm{CCl}_{4}$ concentration of $(175.0 \pm 70.9) \mathrm{pptV}$ (except the extremely high value of $1417 \mathrm{pptV}$ ) in August 2011 was generally comparable with $(108.0 \pm 12.5) \mathrm{pptV}$ observed by Sun et al. (2010) in August 2009 in Beijing and (114 \pm 11$) \mathrm{pptV}$ reported by Barletta et al. (2006) from the measurements of 45 cities in China, but was apparently higher than the background values at the Shangdianzi Global Atmosphere Watch Station $((89.4 \pm 0.7) \mathrm{pptV})$ in Beijing (Yao et al., 2010). Although $\mathrm{CCl}_{4}$ used as a cleaning reagent had been banned since 2007 according to the agreements of the Montreal Protocol for China, its usage as a chemical auxiliary should have been phased-out in 2010 (Zurer, 1995). In comparison with background stations, the relatively high $\mathrm{CCl}_{4}$ concentration measured implied that $\mathrm{CCl}_{4}$ might be still used as a chemical auxiliary in Beijing during the sampling period.

\subsection{Diurnal variations}

The diurnal patterns of $\mathrm{PAN}, \mathrm{O}_{3}$, and $\mathrm{CCl}_{4}$ during the whole year are shown in Fig. 2. The diurnal variations of PAN in the seasons other than winter exhibited similar trends to $\mathrm{O}_{3}$, namely maximal values in the late afternoon (ca. 15:00 to 16:00 local time) and minimal values during early morning and midnight. Such diurnal variation trends firstly demonstrated that PAN and $\mathrm{O}_{3}$ are both secondary pollutants formed from photochemical reactions in daytime. On the other hand, NO emitted from vehicle exhaust during rush hours in the late afternoon greatly consumed PAN and $\mathrm{O}_{3}$ through thermal decomposition and titration, respectively. In contrast to other seasons, the diurnal variation of PAN in winter exhibited PAN concentration gradually and slowly increased from early morning to late afternoon. Because atmospheric PAN under the low temperature in winter is very stable, the weak PAN formation through photochemical reactions would accumulate and result in the continually slow increase of PAN concentration. As for $\mathrm{O}_{3}$ during winter, the fast decrease after 16:00 indicated $\mathrm{O}_{3}$ titration by $\mathrm{NO}$ dominated $\mathrm{O}_{3}$ loss.

$\mathrm{CCl}_{4}$, as a primary pollutant, pulse increase of its concentration was frequently observed during the investigating days in each season, indicating pulse sources of $\mathrm{CCl}_{4}$ existed nearby our sampling site, e.g. the $\mathrm{CCl}_{4}$ solvent used in the laboratories in RCEES. In general, the average atmospheric $\mathrm{CCl}_{4}$ concentrations in Beijing were kept nearly constant during days in each season, contrasting to the diurnal variations of other primary pollutants, such as $\mathrm{CO}$ and NO$x$ with high concentrations during rush hours in early morning and later afternoon and with low values in noontime and afternoon. Both sources' strength and dif- 
Table 1 Sample number and the mean, minimum, median and maximum concentrations for PAN, $\mathrm{PPN}, \mathrm{O}_{3}$ and $\mathrm{CCl}_{4}$ in each month (unit: ppbV)

\begin{tabular}{|c|c|c|c|c|c|c|}
\hline Month & Species & $N$ & Mean \pm SD & Min & Median & Max \\
\hline \multirow[t]{4}{*}{ Sep } & PAN & 228 & $3.98 \pm 2.93$ & 0.20 & 3.49 & 12.52 \\
\hline & PPN & 16 & $1.14 \pm 0.39$ & 0.75 & 0.96 & 2.16 \\
\hline & $\mathrm{O}_{3}$ & 88 & $45.0 \pm 25.9$ & 5.13 & 42.47 & 98.00 \\
\hline & $\mathrm{CCl}_{4}$ & 228 & $0.078 \pm 0.055$ & 0.021 & 0.057 & 0.47 \\
\hline \multirow[t]{4}{*}{ Oct } & PAN & 185 & $0.61 \pm 0.48$ & 0.10 & 0.42 & 2.99 \\
\hline & PPN & - & $<\mathrm{DL}$ & $<\mathrm{DL}$ & $<\mathrm{DL}$ & $<\mathrm{DL}$ \\
\hline & $\mathrm{O}_{3}$ & 91 & $16.80 \pm 10.0$ & 0.47 & 18.20 & 44.80 \\
\hline & $\mathrm{CCl}_{4}$ & 185 & $0.073 \pm 0.018$ & 0.029 & 0.066 & 0.18 \\
\hline \multirow[t]{4}{*}{ Nov } & PAN & 195 & $0.73 \pm 0.64$ & 0.14 & 0.48 & 3.80 \\
\hline & PPN & 65 & $0.18 \pm 0.19$ & DL & 0.099 & 0.89 \\
\hline & $\mathrm{O}_{3}$ & 130 & $14.10 \pm 9.00$ & 2.33 & 11.43 & 33.10 \\
\hline & $\mathrm{CCl}_{4}$ & 195 & $0.078 \pm 0.023$ & 0.038 & 0.070 & 0.20 \\
\hline \multirow[t]{4}{*}{ Dec } & PAN & 25 & $0.27 \pm 0.16$ & 0.08 & 0.23 & 0.86 \\
\hline & PPN & - & $<\mathrm{DL}$ & $<\mathrm{DL}$ & $<\mathrm{DL}$ & - \\
\hline & $\mathrm{O}_{3}$ & 106 & $18.70 \pm 11.80$ & 1.80 & 22.10 & 39.70 \\
\hline & $\mathrm{CCl}_{4}$ & 125 & $0.070 \pm 0.012$ & 0.047 & 0.065 & 0.11 \\
\hline \multirow[t]{4}{*}{ Jan } & PAN & 95 & $0.29 \pm 0.16$ & 0.10 & 0.25 & 0.72 \\
\hline & PPN & - & $<\mathrm{DL}$ & $<\mathrm{DL}$ & $<\mathrm{DL}$ & $<\mathrm{DL}$ \\
\hline & $\mathrm{O}_{3}$ & 95 & $18.60 \pm 13.10$ & 2.20 & 16.60 & 40.70 \\
\hline & $\mathrm{CCl}_{4}$ & 95 & $0.069 \pm 0.016$ & 0.054 & 0.066 & 0.196 \\
\hline \multirow[t]{4}{*}{ Feb } & PAN & 117 & $1.89 \pm 2.08$ & 0.33 & 1.02 & 6.76 \\
\hline & PPN & 25 & $0.66 \pm 0.32$ & 0.22 & 0.58 & 1.45 \\
\hline & $\mathrm{O}_{3}$ & 117 & $17.40 \pm 14.50$ & 1.30 & 11.60 & 43.00 \\
\hline & $\mathrm{CCl}_{4}$ & 117 & $0.116 \pm 0.049$ & 0.078 & 0.094 & 0.30 \\
\hline \multirow[t]{4}{*}{ Mar } & PAN & 124 & $0.69 \pm 0.55$ & 0.20 & 0.41 & 2.26 \\
\hline & PPN & 22 & $0.10 \pm 0.07$ & 0.03 & 0.09 & 0.34 \\
\hline & $\mathrm{O}_{3}$ & 124 & $29.9 \pm 12.8$ & 1.30 & 34.30 & 44.90 \\
\hline & $\mathrm{CCl}_{4}$ & 124 & $0.105 \pm 0.023$ & 0.083 & 0.096 & 0.22 \\
\hline \multirow[t]{4}{*}{ Apr } & PAN & 183 & $1.36 \pm 0.97$ & 0.20 & 1.08 & 4.83 \\
\hline & PPN & 3 & $0.11 \pm 0.03$ & 0.08 & 0.13 & 0.14 \\
\hline & $\mathrm{O}_{3}$ & 185 & $34.00 \pm 13.40$ & 0.90 & 35.20 & 75.40 \\
\hline & $\mathrm{CCl}_{4}$ & 183 & $0.113 \pm 0.038$ & 0.077 & 0.10 & 0.28 \\
\hline \multirow[t]{4}{*}{ May } & PAN & 244 & $2.29 \pm 2.26$ & 0.34 & 1.35 & 11.50 \\
\hline & PPN & 112 & $0.77 \pm 0.56$ & 0.09 & 0.56 & 2.50 \\
\hline & $\mathrm{O}_{3}$ & 243 & $51.70 \pm 17.90$ & 7.10 & 51.60 & 111.90 \\
\hline & $\mathrm{CCl}_{4}$ & 244 & $0.12 \pm 0.1$ & 0.059 & 0.1 & 1.087 \\
\hline \multirow[t]{4}{*}{ Jun } & PAN & 146 & $3.77 \pm 2.82$ & 0.37 & 2.70 & 12.10 \\
\hline & PPN & 78 & $0.56 \pm 0.52$ & 0.08 & 0.37 & 2.30 \\
\hline & $\mathrm{O}_{3}$ & 146 & $72.10 \pm 38.4$ & 10.5 & 65.4 & 146.20 \\
\hline & $\mathrm{CCl}_{4}$ & 146 & $0.152 \pm 0.113$ & 0.08 & 0.116 & 0.746 \\
\hline \multirow[t]{4}{*}{ Jul } & PAN & 156 & $1.86 \pm 1.64$ & 0.18 & 1.28 & 8.90 \\
\hline & PPN & 73 & $0.54 \pm 0.33$ & 0.07 & 0.47 & 1.83 \\
\hline & $\mathrm{O}_{3}$ & 150 & $61.90 \pm 28.80$ & 10.90 & 51.90 & 142.90 \\
\hline & $\mathrm{CCl}_{4}$ & 156 & $0.127 \pm 0.038$ & 0.091 & 0.115 & 0.276 \\
\hline \multirow[t]{4}{*}{ Aug } & PAN & 219 & $2.32 \pm 1.28$ & 0.26 & 2.02 & 6.17 \\
\hline & PPN & 46 & $0.38 \pm 0.23$ & 0.09 & 0.34 & 1.14 \\
\hline & $\mathrm{O}_{3}$ & 217 & $84.10 \pm 35.40$ & 6.90 & 84.40 & 173 \\
\hline & $\mathrm{CCl}_{4}$ & 219 & $0.181 \pm 0.110$ & 0.086 & 0.153 & 1.417 \\
\hline
\end{tabular}

DL: Detection limit of PPN (36 pptV).

fusion condition dominate the atmospheric concentrations of primary pollutants, if the sources' strength was constant for a pollutant during a day, the diurnal variation of the pollutant would exhibit minimum in noontime or afternoon when fast gas diffusion usually occurs because of elevation of atmospheric boundary layer. The relative stable values of atmospheric $\mathrm{CCl}_{4}$ during the days indicated its fast diffusion in noontime or afternoon was greatly counteracted by its increasing evaporation rates from solvents under elevation of air temperature. 

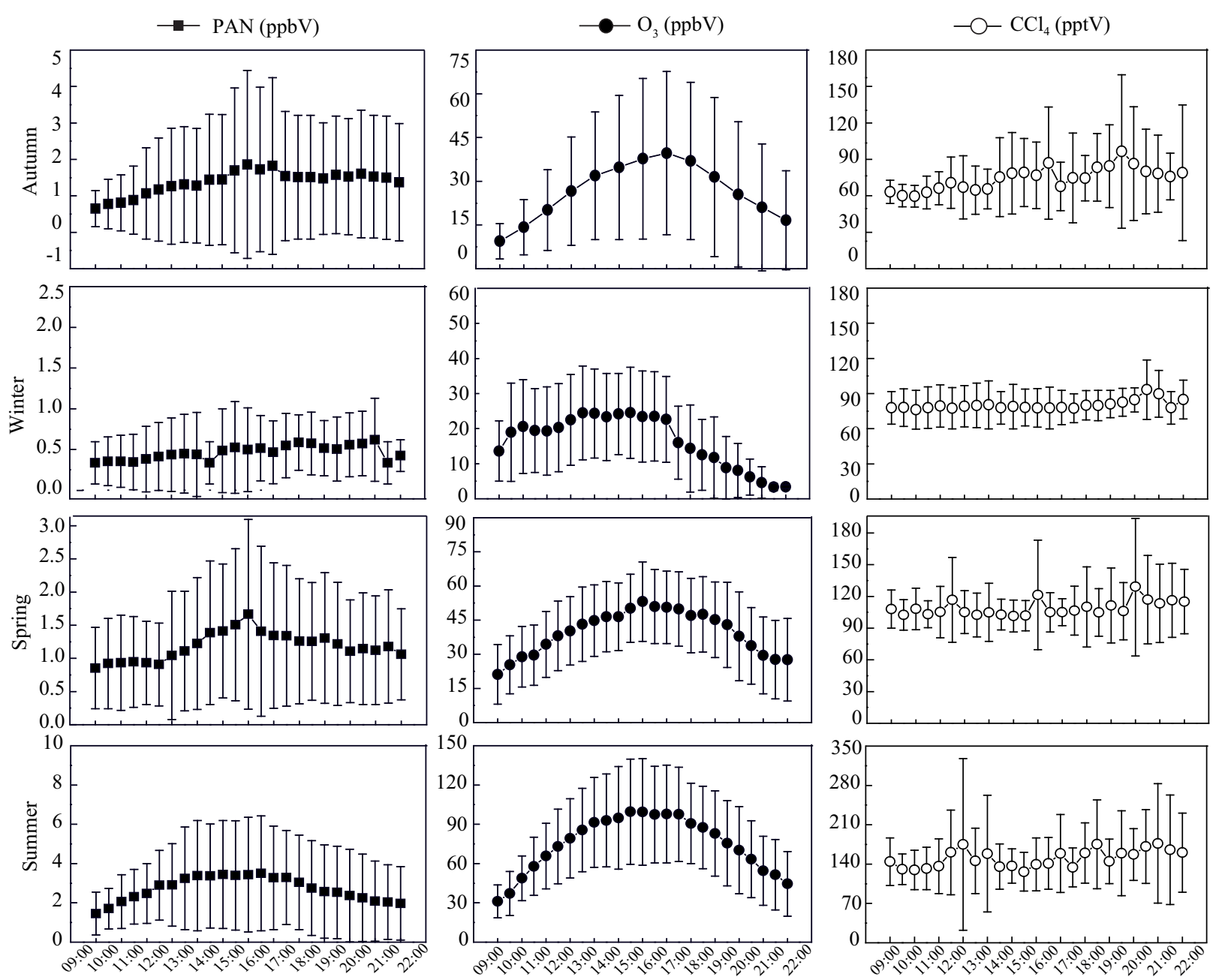

Fig. 2 Diurnal patterns of $\mathrm{PAN}, \mathrm{O}_{3}$, and $\mathrm{CCl}_{4}$ during the autumn of 2010 to the summer of 2011. Error bars represent standard deviations.

\subsection{Correlation between PAN and PPN}

Atmospheric PPN and PAN have very similar formation mechanisms through the photochemical reactions of VOCs with NOx and would be expected to be strongly correlated. As shown in Fig. 3, significant positive correlations between PAN and PPN in each season were indeed found in this study. The overall correlation between PAN and concurrent PPN during the whole measurement period was quantified by the linear regression as PPN $=(0.152 \pm$ $0.005)$ PAN $-(-0.025 \pm 0.022)(N=440, R=0.84$, $P<0.0001$ ). The slope (or the ratio of PPN/PAN) of 0.152 was well within the range $(0.135-0.172)$ reported in polluted areas (Grosjean et al., 1993; Kourtidis et al., 1993; Ridley et al., 1990). The VOCs precursors for PAN have been recognized to be emitted from both anthropogenic and biogenic sources whereas the precursors for PPN (propanal and 1-butene) are predominantly from anthropogenic sources (Grosjean et al., 2001; Roberts et al., 2004). Therefore, the ratio of PPN/PAN has been widely used as an indicator for distinguishing the contribution of anthropogenic hydrocarbons from biogenic hydrocarbons to atmospheric PANs. Through the regression of a linear multivariate correlation involving PAN and PPN, Roberts et al. $(2002,2004)$ concluded that when the ratio of PPN/PAN is between $13.5 \%$ and $17.2 \%$, PANs formation was dominated by anthropogenic hydrocarbons, while dominated by biogenic hydrocarbons when the ratio is lower than $10 \%$. The average ratio of PPN/PAN (15.2\%) obtained by this study implied that the PANs formation in Beijing was dominated by anthropogenic hydrocarbons emission.

\subsection{Correlation between PAN and $\mathrm{O}_{3}$}

The net production of $\mathrm{O}_{3}$ in the troposphere is derived from the photochemical conversion of $\mathrm{NO}$ to $\mathrm{NO}_{2}$ through the organic peroxy radical oxidation. Peroxyacetyl radical, as an important component of peroxy radicals, also participates in $\mathrm{O}_{3}$ production, and generates PAN via its reaction with $\mathrm{NO}_{2}$ in the atmosphere. Therefore, a positive correlation between PAN and $\mathrm{O}_{3}$ is expected and has been reported in the summer and autumn daytime in Beijing (Liu et al., 2010; Wang and Zhang, 2007; Yang et al., 


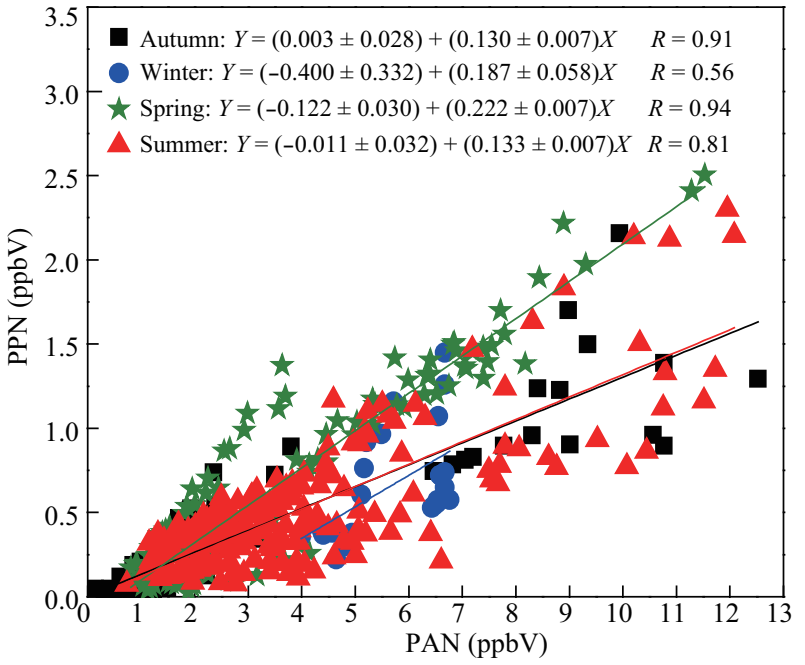

Fig. 3 Linear regressions between PAN and concurrent PPN as a function of season.

2009) and in other urban areas, i.e., Porto Alegre, Brazil (Grosjean et al., 2002) and Munich (Rappengluck et al., 1993).

In this study, only the data between 11:00-16:00 local time when photochemical reactions are most intensive were analyzed for demonstrating the correlation between PAN and $\mathrm{O}_{3}$. The linear correlation coefficients $(R)$ and the slopes $\left(\Delta \mathrm{O}_{3} / \Delta \mathrm{PAN}\right)$ of the correlations in each month are illustrated in Fig. 4. The fairly positive correlations between PAN and $\mathrm{O}_{3}$ were found from May to September with $R$ ranging from 0.56 to 0.92 , indicating that both atmospheric PAN and $\mathrm{O}_{3}$ in Beijing during these photochemical reactive months were dominated by local formation. No significant correlations were found in March, April, October and November with $R$ ranging from -0.2 to 0.2 , indicating that atmospheric $\mathrm{PAN}$ and $\mathrm{O}_{3}$ might be governed by complex sources, including local photochemical formation, long range transportation, diffusion from the upper atmosphere. Significant negative correlations were found in the three winter months (December, January, and February) with $R$ ranging from -0.69 to -0.75 . During winter season in Beijing, photochemical reactivity becomes extremely low as shown the extremely low concentrations of $\mathrm{O}_{3}$ and PAN. In addition, the atmospheric boundary in winter becomes low, which favors for pollutants accumulation, for example, the most frequent haze days have been found during winter in Beijing (Sun et al., 2006; Wang et al., 2006). The accumulation of NO emitted from vehicle exhaust could consume large quantity of $\mathrm{O}_{3}$ through titration reaction, whereas PAN consumption through thermal decomposition coupling with NO reaction became extremely low as the low temperature in winter. Both the accumulation of PAN formed through weak photochemical reactions (mainly initiated by $\mathrm{OH}$ from HONO photolysis) and consumption of $\mathrm{O}_{3}$ by $\mathrm{NO}$ were responsible for the significant negative correlations during

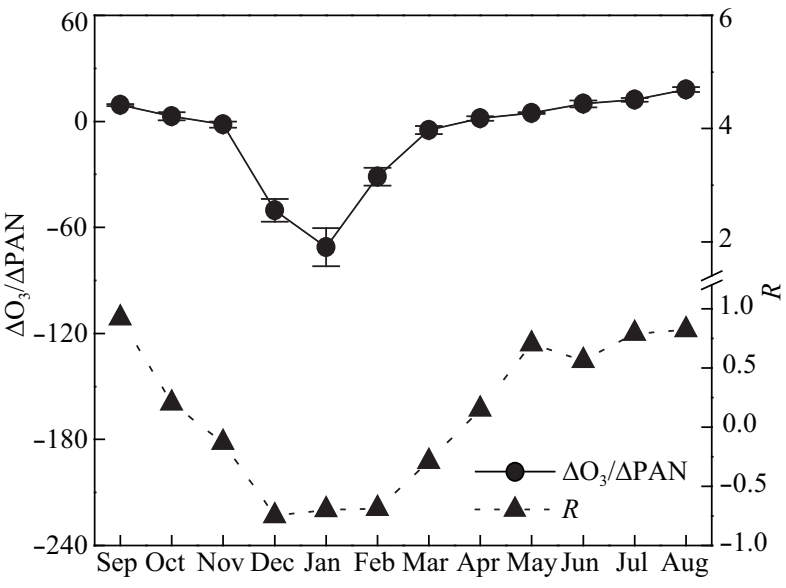

Fig. 4 PAN $/ \mathrm{O}_{3}$ slope plotted as a function of month. The error bars represented the $1 \sigma$ deviation for the slopes. The determined coefficient $R$ was shown for the monthly linear regression.

winter seasons. A similar yearly trend of $\Delta \mathrm{O}_{3} / \Delta \mathrm{PAN}$ was also observed in 2-years data recorded at the upper Midwest site (Pippin et al., 2001) and in 5-years data obtained at a rural site in eastern Canada (Bottenheim et al., 1994).

The $\Delta \mathrm{O}_{3} / \triangle \mathrm{PAN}$ values obtained by this study in the summer months were 9.92-18.0, which were close to the value of 18.87 reported by Zhang et al. (2011) in August 2006 in Beijing, but were generally lower than the values reported in other cities (e.g. 24.3 reported at an urban site of Ontario by Shepson et al., 1992), in forest regions (e.g., 38.2-81.9 reported by Pippin et al., 2001), and at rural sites (e.g. 39.01 reported by Hartsell et al., 1994). Shepson et al. (1992) found $\Delta \mathrm{O}_{3} / \triangle \mathrm{PAN}$ increased substantially from urban (24.3) to rural (70.6) air masses, Pippin et al. (2001) also found that the extremly greater values $\left(\Delta \mathrm{O}_{3} / \Delta \mathrm{PAN}\right.$ : 76.6-81.9) observed in summer of 1998 than those $\left(\Delta \mathrm{O}_{3} / \Delta \mathrm{PAN}\right.$ : 38.2-45.1) oberved in summer of 1997 was consistent with regions impacted by less polluted air masses. Therefore, the $\Delta \mathrm{O}_{3} / \Delta \mathrm{PAN}$ can be used as an indicator for air pollution status, that is, the less values of $\Delta \mathrm{O}_{3} / \triangle \mathrm{PAN}$ mean serious pollution. As compared above, the relatively low values of $\Delta \mathrm{O}_{3} / \triangle \mathrm{PAN}$ in summers of Beijing implied that Beijing is suffering serious air pollution.

\section{Conclusions}

Atmospheric PAN, PPN, $\mathrm{O}_{3}$, and $\mathrm{CCl}_{4}$ were simultaneously measured from September 2010 to August 2011 in Beijing. The common seasonal variations of the pollutants revealed that high values usually occurred from late spring to early autumn and minimal values in winter. The seasonal variations of PAN, PPN and $\mathrm{O}_{3}$, typical secondary pollutants, well reflected the seasonal variation trend of photochemical reactivity in Beijing, and that of $\mathrm{CCl}_{4}$, 
typical primary pollutant, revealed that air temperature is the dominant factor affecting $\mathrm{CCl}_{4}$ evaporation from solvents. The abnormal high values of PAN, PPN and $\mathrm{CCl}_{4}$ observed in February were ascribed to the accumulation of the pollutants formed from weak photochemical reactions for PAN and PPN or primary emission for $\mathrm{CCl}_{4}$ under the frequent haze days occurred in the month.

The significant positive correlation between PAN and PPN during the whole investigating period further confirmed that they are from similar formation mechanisms, and the ratio of $\Delta \mathrm{O}_{3} / \triangle \mathrm{PAN}$ indicated anthropogenic VOCs were their dominant precursors in the megacity.

PAN and $\mathrm{O}_{3}$ exhibited a strong positive correlation in the summer with $\Delta \mathrm{O}_{3} / \triangle \mathrm{PAN}$ ranging from 9.92 to 18.0. In comparison with other measurements in different areas, the relatively low values of $\Delta \mathrm{O}_{3} / \Delta \mathrm{PAN}$ in Beijing indicated serious air pollution in the megacity. The strong negative correlation between PAN and $\mathrm{O}_{3}$ in the months of winter reflected strong $\mathrm{O}_{3}$ consumption by $\mathrm{NO}$ titration and less thermal decomposition of PAN.

\section{Acknowledgments}

This work was supported by the National Natural Science Foundation of China (No. 41075094, 21177140, 20977097), the Strategic Priority Research Program of the Chinese Academy of Sciences (No. XDB05010100), and the National Basic Research Program (973) of China (No. 2010CB732304).

\section{R E F E R E N C E S}

Aikin A C, Herman J R, Maier E J, Mcquillan C J, 1982. Atmospheric chemistry of ethane and ethylene. Journal of Geophysical Research-Oceans and Atmospheres, 87(C4): 3105-3118.

Altshuller A P, 1976. Average tropospheric concentration of carbon tetrachloride based on industrial production, usage, and emissions. Environmental Science and Technology, 10(6): 596-598.

Altshuller A P, 1978. Assessment of the contribution of chemical species to the eye irritation potential of photochemical smog. Journal of the Air Pollution Control Association, 28(6): 594-598.

Barletta B, Meinardi S, Simpson I J, Sherwood R F, Chan C Y, Wang X et al., 2006. Ambient halocarbon mixing ratios in 45 Chinese cities. Atmospheric Environment, 40(40): 7706-7719.

Bottenheim J W, Sirois A, Brice K A, Gallant A J, 1994. Five years of continuous observations of PAN and ozone at a rural location in eastern Canada. Journal of Geophysical Research-Atmospheres, 99(D3): 5333-5352.

Cox R A, Derwent R G, Eggleton A E J, Lovelock J E, 1976. Photochemical oxidation of halocarbons in the troposphere. Atmospheric Environment, 10(4): 305-308.

Derwent R, Simmonds P, O'doherty S, Ryall D, 1998. The impact of the Montreal protocol on halocarbon concentrations in northern hemisphere baseline and European air masses at Mace Head, Ireland over a ten year period from 1987-1996. Atmospheric Environment, 32(21): 3689-3702.
Gaffney J S, Marley N A, 2001a. Comment on "Environmental implications on the oxygenation of gasoline with ethanol in the metropolitan area of Mexico City". Environmental Science and Technology, 35(24): 4957-4958.

Gaffney J S, Marley N A, 2001b. Peroxyacetyl nitrate (PAN): historical perspective. In: Proceedings of the 81stAMS Annual Meeting. A Millennium Symposium on Atmospheric Chemistry. Albuquerque, NM. 14-19 January.

Gao Y, Zhang M G, 2012. Sensitivity analysis of surface ozone to emission controls in Beijing and its neighboring area during the 2008 Olympic Games. Journal of Environmental Sciences, 24(1): $50-61$.

Grosjean D, Williams E L, Grosjean E, 1993. Peroxyacyl nitrates at southern california mountain forest locations. Environmental Science and Technology, 27(1): 110-121.

Grosjean E, Grosjean D, Woodhouse L F, 2001. Peroxyacetyl nitrate and peroxypropionyl nitrate during SCOS97-NARSTO. Environmental Science and Technology, 35(20): 4007-4014.

Grosjean E, Grosjean D, Woodhouse L F, Yang Y J, 2002. Peroxyacetyl nitrate and peroxypropionyl nitrate in Porto Alegre, Brazil. Atmospheric Environment, 36(14): 2405-2419.

Hansel A, Wisthaler A, 2000. A method for real-time detection of PAN, PPN and MPAN in ambient air. Geophysical Research Letters, 27(6): 895-898.

Happell J D, Roche M P, 2003. Soils: A global sink of atmospheric carbon tetrachloride. Geophysical Research Letters, 30(2): 1088.

Hartsell B E, Aneja V P, Lonneman W A, 1994. Relationships between peroxyacetyl nitrate, $\mathrm{O}_{3}$, and $\mathrm{NO} y$ at the rural southern oxidants study site in central piedmont, North-Carolina, Site Sonia. Journal of Geophysical Research-Atmospheres, 99(D10): 21033-21041.

Honrath R E, Hamlin A J, Merrill J T, 1996. Transport of ozone precursors from the Arctic troposphere to the North Atlantic region. Journal of Geophysical Research-Atmospheres, 101(D22): 29335-29351.

Kleindienst T E, Shepson P B, Smith D F, Hudgens E E, Nero C M, Cupitt $\mathrm{L} \mathrm{T}$ et al., 1990. Comparison of mutagenic activities of several peroxyacyl nitrates. Environmental and Molecular Mutagenesis, 16(2): 70-80.

Kondo Y, Koike M, Kawakami S, Singh H B, Nakajima H, Gregory G L et al., 1997. Profiles and partitioning of reactive nitrogen over the Pacific Ocean in winter and early spring. Journal of Geophysical Research, 102(D23): 28405-28424.

Kourtidis K A, Fabian P, Zerefos C, Rappengluck B, 1993. Peroxyacetyl nitrate (PAN), peroxypropionyl nitrate (PPN) and PAN/ozone ratio measurements at 3 sites in Germany. Tellus Series B-Chemical and Physical Meteorology, 45(5): 442-457.

Lee G, Jang Y, Lee H, Han J S, Kim K R, Lee M, 2008. Characteristic behavior of peroxyacetyl nitrate (PAN) in Seoul megacity, Korea. Chemosphere, 73(4): 619-628.

Liu Z, Wang Y H, Gu D S, Zhao C, Huey L G, Stickel R et al., 2010. Evidence of reactive aromatics as a major source of peroxy acetyl nitrate over China. Environmental Science and Technology, 44(18): 7017-7022.

Lovelock J E, Maggs R J, Wade R J, 1973. Halogenated hydrocarbons in and over the Atlantic. Nature, 241(5386): 194-196.

Marley N A, Gaffney J S, Ramos-Villegas R, Gonzalez B C, 2007. Comparison of measurements of peroxyacyl nitrates and primary carbonaceous aerosol concentrations in Mexico City determined in 1997 and 2003. Atmospheric Chemistry and Physics, 7(9): 2277- 
2285.

McFadyen G G, Cape J N, 2005. Peroxyacetyl nitrate in eastern Scotland. Science of the Total Environment, 337(1-3): 213-222.

Molina M J, Rowland F S, 1974. Stratospheric sink for chlorofluoromethanes: Chlorine atomcatalysed destruction of ozone. Nature, 249(5460): 810-812.

Pang X B, Mu Y J, 2006. Seasonal and diurnal variations of carbonyl compounds in Beijing ambient air. Atmospheric Environment, 40(33): 6313-6320.

Pippin M, Bertman S, Thornberry T, Town M, Carroll M A, Sillman S, 2001. Seasonal variations of PAN, PPN, and $\mathrm{O}_{3}$ at the upper Midwest PROPHET site. Journal of Geophysical ResearchAtmospheres, 106(D20): 24451-24463.

Rappengluck B, Kourtidis K, Fabian P, 1993. Measurements of ozone and peroxyacetyl nitrate (PAN) in Munich. Atmospheric Environment Part B-Urban Atmosphere, 27(3): 293-305.

Ridley B A, Shetter J D, Walega J G, Madronich S, Elsworth C M, Grahek F E et al., 1990. The behavior of some organic nitrates at Boulder and Niwot Ridge, Colorado. Journal of Geophysical Research-Atmospheres, 95(D9): 13949-13961.

Roberts J M, Flocke F, Chen G, de Gouw J, Holloway J S, Hubler $\mathrm{G}$ et al., 2004. Measurement of peroxycarboxylic nitric anhydrides (PANs) during the ITCT 2K2 aircraft intensive experiment. Journal of Geophysical Research-Atmospheres, 109(D23). DOI: 10.1029/2004JD004960.

Roberts J M, Flocke F, Stroud C A, Hereid D, Williams E, Fehsenfeld F et al., 2002. Ground-based measurements of peroxycarboxylic nitric anhydrides (PANs) during the 1999 southern oxidants study Nashville intensive. Journal of Geophysical ResearchAtmospheres, 107(D21): 1-10.

Roberts J M, Tanner R L, Newman L, Bowersox V C, Bottenheim J W, Anlauf K G et al., 1995. Relationships between PAN and ozone at sites in eastern North-America. Journal of Geophysical ResearchAtmospheres, 100(D11): 22821-22830.

Shao M, Lu S H, Liu Y, Xie X, Chang C C, Huang S et al., 2009. Volatile organic compounds measured in summer in Beijing and their role in ground-level ozone formation. Journal of Geophysical ResearchAtmospheres, 114(D2). DOI: 10.1029/2008JD010863.

Shepson P B, Hastie D R, So K W, Schiff H I, 1992. Relationships between PAN, PPN and $\mathrm{O}_{3}$ at urban and rural sites in Ontario. Atmospheric Environment Part A-General Topics, 26(7): 12591270.

Shepson P B, Kleindienst T E, Edney E O, Nero C M, Cupitt L T, Claxton L D, 1986. Acetaldehyde: the mutagenic activity of its photooxidation products. Environmental Science and Technology, 20(10): 1008-1013.

Simmonds P, Cunnold D, Alyea F, Cardelino C, Crawford A, Prinn R et al., 1988. Carbon tetrachloride lifetimes and emissions determined from daily global measurements during 1978-1985. Journal of Atmospheric Chemistry, 7(1): 35-58.

Singh H B, 1987. Reactive nitrogen in the troposphere. Environmental Science and Technology, 21(4): 320-327.

Singh H B, Hanst P L, 1981. Peroxyacetyl nitrate (PAN) in the unpolluted atmosphere-An important reservoir for nitrogen-oxides. Geophysical Research Letters, 8(8): 941-944.

Singh H B, Herlth D, Kolyer R, Salas L, Bradshaw J D, Sandholm S T et al., 1996. Reactive nitrogen and ozone over the western Pacific: distribution, partitioning, and sources. Journal of Geophysical
Research-Atmospheres, 101(D1): 1793-1808.

Singh H B, Herlth D, Ohara D, Salas L, Torres A L, Gregory G L et al., 1990. Atmospheric peroxyacetyl nitrate measurements over the Brazilian Amazon basin during the wet season-relationships with nitrogen-oxides and ozone. Journal of Geophysical ResearchAtmospheres, 95(D10): 16945-16954.

Singh H B, Ohara D, Herlth D, Bradshaw J D, Sandholm S T, Gregory G L et al., 1992. Atmospheric measurements of peroxyacetyl nitrate and other organic nitrates at high latitudes: possible sources and sinks. Journal of Geophysical Research-Atmospheres, 97(D15): 1651116522.

Sun E J, Huang M H, 1995. Detection of peroxyacetyl nitrate at phytotoxic level and its effects on vegetation in Taiwan. Atmospheric Environment, 29(21): 2899-2904.

Sun X Z, Wan D, Shi Y H, Zhang J B, Hu J X, 2010. Concentrations and trends of $\mathrm{CFCs}$ and $\mathrm{CCl}_{4}$ in the atmosphere of Beijing. Research of Environmental Science, 23(6): 674-679.

Sun Y, Zhuang G, Tang A, Wang Y, An Z, 2006. Chemical characteristics of $\mathrm{PM}_{2.5}$ and $\mathrm{PM}_{10}$ in haze-fog episodes in Beijing. Environmental Science and Technology, 40(10): 3148-3155.

Tang G, Li X, Wang Y, Xin J, Ren X, 2009. Surface ozone trend details and interpretations in Beijing, 2001-2006. Atmospheric Chemistry and Physics, 9(22): 8813-8823.

Taylor O, 1969. Importance of peroxyacetyl nitrate (PAN) as a phytotoxic air pollutant. Journal of the Air Pollution Control Association, 19(5): 347-351.

Wang B, Shao M, Roberts J M, Yang G, Yang F, Hu M et al., 2010. Ground-based on-line measurements of peroxyacetyl nitrate (PAN) and peroxypropionyl nitrate (PPN) in the Pearl River Delta, China. International Journal of Environmental Analytical Chemistry, 90(7): 548-559.

Wang B, Zhang J B, 2007. Monitoring and analysis of PAN and PPN in the air of Beijing during the summer of 2005. Environmental Science, 28(7): 1621-1626.

Wang T, Ding A J, Gao J, Wu W S, 2006. Strong ozone production in urban plumes from Beijing, China. Geophysical Research Letters, 33(21). DOI: 10.1029/2006GL027689.

Wang Y, Zhuang G S, Sun Y L, An Z S, 2006. The variation of characteristics and formation mechanisms of aerosols in dust, haze, and clear days in Beijing. Atmospheric Environment, 40(34): 65796591.

Watanabe I, Nakanishi M, Tomita J, Hatakeyama S, Murano K, Mukai H et al., 1998. Atmospheric peroxyacyl nitrates in urban/remote sites and the lower troposphere around Japan. Environmental Pollution, 102(1): 253-261.

Williams E L, Grosjean D, 1991. Peroxypropionyl nitrate at a southern California mountain forest site. Environmental Science and Technology, 25(4): 653-659.

Xu Z, Zhang J, Yang G, Hu M, 2011. Acyl peroxy nitrate measurements during the photochemical smog season in Beijing, China. Atmospheric Chemistry and Physics Discussion, 11(3): 10265-10303.

Yang G, Zhang J B, Wang B, 2009. Analysis on correlation and concentration variation of atmospheric PAN and PPN in Beijing. Acta Scientiarum Naturalium Universitatis Pekinensis, 45(1): 144150.

Yao B, Zhou L X, Zhang F, Xu L, Zang K P, Zhang X C et al., 2010. In-situ measurement of atmospheric carbon tetrachloride $\left(\mathrm{CCl}_{4}\right)$ at the Shangdianzi global atmosphere watch regional station. Acta 
Scientiae Circumstantiae, 30(12): 2377-2382.

Zhang G, Mu Y, Liu J, Mellouki A, 2012. Direct and simultaneous determination of trace-level carbon tetrachloride, peroxyacetyl nitrate, and peroxypropionyl nitrate using gas chromatographyelectron capture detection. Journal of Chromatography A, 1266: $110-115$

Zhang J, Xu Z, Yang G, Wang B, 2011. Peroxyacetyl nitrate (PAN) and peroxypropionyl nitrate (PPN) in urban and suburban atmospheres of Beijing, China. Atmospheric Chemistry and Physics Discussions, 11(3): 8173-8026.

Zhang J B, Tang X Y, 1994. Atmospheric PAN measurements and the formation of PAN in various systems. Environmental Chemistry,
13(1): 30-39.

Zhang J M, Wang T, Ding A J, Zhou X H, Xue L K, Poon C N et al., 2009. Continuous measurement of peroxyacetyl nitrate (PAN) in suburban and remote areas of western China. Atmospheric Environment, 43(2): 228-237.

Zhang Y C, Hu H L, Tan K, Liu X Q, Shao S S, Yang G C et al., 2004. Dial measurements of $\mathrm{SO}_{2}, \mathrm{NO}_{2}$, and $\mathrm{O}_{3}$ in Beijing. In: Proceedings of the 22nd International Laser Radar Conference (Ilrc 2004). Matera, Italy. 12-16 July. Vols 1 and 2,561: 721-724.

Zurer P S, 1995. Delayed CFC phase out in developing-countries raises growing concern. Chemical and Engineering News, 73(19): 25-26. 